\title{
Comparatisms Compared: Stirring the Appetite
}

\author{
CAIUS DOBRESCU
}

Comparative Literature in Europe: Challenges and Perspectives. Edited by Nikol Dziub and Frédérique Toudoire-Surlapierre. Cambridge Scholars Publishing, 2019.

What is truly remarkable about the collection of studies Comparative Literature in Europe: Challenges and Perspectives is the breadth of problems, perspectives and concepts exposed in a mere 240 pages. The editors, Nikol Dziub and Frédérique Toudoire-Surlapierre, have no ambition to provide a uniform coverage of all academic cultures definable as European, but attempted to prove that even a somewhat contingent reunion of national experiences reveals a spectacular entanglement of means and goals.

The editors omit the reason for the absence of determinant players on the European market of comparatism, such as France, UK, Germany, Italy, or the Scandinavian countries. It is almost on a casual note that, in her "Practical Introduction", Nikol Dziub mentions the emphasis placed on 'usually "invisible" countries' (p. 15). But the suggestion is that the interface between the highly "visible" France and Germany (Dziub and Toudoire-Surlapierre teach at the Université de Haute-Alsace) is the best position for evaluating the extent to which the "minor" can contain the complexities of the "major". Conversely, at least one contribution (César Domínguez's "Comparative Literature and New Hispanisms") shows that global linguistic and literary cultures can also experience the conflicts and insecurities of those contained between far less generous borders.

The complexity is not given only, or primarily, by the range of countries taken into account (which, nevertheless, is comfortably large - in order of their appearance: Spain, Portugal, Ireland, Ukraine, Finland, Belgium, Luxembourg, Austria, Switzerland, Romania, Estonia, Lithuania, Slovakia, Macedonia, Poland). The "horizontal" diversity of national languages and traditions is interspersed by the "vertical" diversity of perspectives on the history and present condition of comparative literature: the intellectual and the institutional, the socio-political and the socio-cultural.

The first two parts of the collection stress geo-political determinations, in their intimate connection with the evolutions of representations of 
identity, language, literature, and, accordingly, comparative literature. The first section tackles from both ends the legacy of modern European empires. The complexity and sensitivity of the matter is made obvious from the very beginning by the use of "decoloniality" against the dominant notion of "postcolonialism." The nuance captures, on the one hand, the interplay of perspectives: former colonial powers (Spain and Portugal, in this case) commune with former colonies (Ireland and Ukraine). On the other hand, decoloniality might also suggest an extension from the well-documented colonialism of West-European (here, Iberian and British/English), to its EastEuropean version (unmistakably, the Tsarist/Soviet/Russian one).

César Domínguez focuses his survey on language policies, as complex (post)imperial power plays and as major influences on the evolution of literary studies. The influence works either through the remnant imperialism of "Spanish" global studies (occasionally peaking on "negationism" or "historical revisionism" - pp. 30-1), or, in a reversed, contrarian manner, through the gradual autonomization of Latin-American or Iberian studies. Dominguez exposes the challenges of monoglossic comparatism, i.e. of exploring the dynamics of similarity and differentiation within the global area covered by Spanish, but also the reverberation in the field of comparative literature of identity tensions such as the one furthering Catalan independentism. The Portuguese scenery appears, in comparison, as more serene (thereby suggesting a deeper detachment from the colonial past). Actually, Ângela Fernandes chooses to focus rather on the history of the discipline, and to specific problems of the ethos of literary studies (as when invoking the concern expressed by Álvaro Manuel Machado, most certainly shared by many fellow scholars all over Europe, even if only a few dare to openly articulate it, that cultural studies and sociologically-minded approaches tend to "replace and often suffocate" Portuguese literary comparatism - p. 45).

Brigitte Le Juez takes another route for presenting the complex fate of comparative literature in Ireland. She carefully articulates a historical view on the linguistically divided cultural consciousness of the nation (Gaelic vs. English) with a careful exploration of the curricular policies and institutionalization process of comparative literary studies. In her contribution on Ukraine, Nikol Dziub sets the template for all the other East-European countries represented in the selection. The presentation begins by unearthing the origins of the discipline. It goes on to the development of comparative literature in the context of the general $19^{\text {th }}$-century aspirations (not always concluded) towards founding nation states - a process implying both arguing for a distinct national spirit, and working to validate it before the imaginary 
court of the civilized world (to put it in the terms of the Slovak contributor, Robért Gáfrik: "the individualisation of literatures on the national principle was the starting point for their comparison", p. 192). Then, the Soviet epoch, dual in point of approach and effect: on the one side condemning comparative literature as "bourgeois", on the other, imperatively promoting an artificial universalism cum progressivism. Later phases of the Communist regime witness the gradual and partial transformation of comparative literature in a covert trench for regenerating a sense of liberal and cosmopolitanism national identity opposed to the Soviet ideological colonialism, while the post-Communist epoch creates the opportunity of an actual connection to the global scientific community, and to its ever more eclectic theoretical and methodological agenda ("Contemporary Ukrainian comparatism has six keywords: contacts, typology, genres, intermediality, postcolonialism and imagology. Ukrainian comparatism is not anti-colonial anymore, it is postcolonial - which means that it does not try anymore to fight for peripheral cultures against Russian imperialism”, p. 76).

The second section of the book, "Comparative Literature and CrossCultural Studies," focuses on cases of what we could call micro-multiculturalism. It collects cases of "small" bi- or multi-lingual nations that should have been naturally predisposed to developing strong comparative literature projects. But besides the communal criterion of size, the situations considered vary quite liberally, as do the angles of approach chosen by the contributors. In his report on comparatism in Finland, Harri Veivo addresses the country's literary bilingualism (Finnish and Swedish) stating that "from the very beginning, the dividing line between the foreign and the own, and between the varying forms of own, has been porous" (p. 91). However, his paper focuses not on this historical peculiarity, but on the large and dynamic theoretical forefront of local comparatism. Apparently, in Finland the identity crisis touches not on the ethno-cultural but on the conceptual and the epistemic, implying the quest for a reasonably stable and definite condition of comparative literature within the domestic and international tableau of the humanities. It is inspiring to learn that, besides a profound absorption of contemporary conceptual and methodological evolutions, Finnish scholars do not content themselves to be conceptual debtors, but take a critical and prospective stand in the hottest debates of international comparatism (in support of this Veivo quotes, among others, the contributions of Päivi Lappalainen and Liisa Steinby).

In his survey of Belgian comparatism, Michel Delville presents the picture of an as vivid theoretical and research field as you would expect from a scholarly community situated "within an always comparative and multilingual space at 
the same time as they become confronted with the increasingly complex and intricate realities of globalization" (p. 96). Nevertheless, Delville quotes the bewilderment, recurrent in domestic disciplinary self-questioning, that besides its wide opening towards an international agenda, literary comparatism is rarely resorted to in the dialogue between the Flemish and the French halves of Belgian identity. Among a diversity of research projects, Delville focuses on those that foreground the tradition of the Walloon-Flemish cosmopolitan multiculturalism, such as Jan Baetens and Michael Kasper's editing and translating into English of the entire collection of Correspondences, the first tribune of Belgian Surrealism.

A higher sense of cultural community is outlined by Jeanne Glesener, in her vivid account of the manner in which literary comparatism both brings to expression and nurtures the triple linguistic/cultural identity of Luxembourg (French, German, and properly Luxembourgish). The Austrian case, covered by Sandra Vlasta, is more complicated, since Austrian literature cannot by any measure count as bi-lingual. Its inclusion is therefore motivated rather by Austria's implicit multicultural heritage, as the former core of the Hapsburg Central-European commonwealth. Indeed, the interests of the Innsbruck University seem to conserve something of the said heritage, considering their professed partiality to neighboring Slavic cultures (in a spirit called comparer en Autriche, p. 120 - or, perhaps, à l'autrichienne). But the connection to the days of Felix Austria might be only an illusion, given, on the one hand, the lack of interest in other vectors of the imperial past (first of all, Hungarian, but also Italian, or Romanian for that matter), and, on the other, the predominant leaning of actual research and teaching toward theoretical questions, rather than recovering embedded (post)imperial histories (according to Vlasta, Innsbruck programs concentrate mainly on the theory of intermediality, concepts of world literature, narratology, concepts of culture - p. 121). The other Austrian center of comparatist research is the University of Vienna, which is said to favor the study of literature within pan-(Western)European social-cultural processes, especially from early modernity on.

Intentionally or not, the provocative conclusions of this section appear to be drawn by Thomas Hunkeler in his essay inquisitively titled "Switzerland, the Ideal Republic of Comparative Literature?” With a self-critical spirit touching on the caustic, matched, in the present selection, only by the Polish contributor Ewa Łukaszyk, Hunkeler states that, in spite of outsider expectations, in historically multicultural and multilingual Switzerland comparative literature is rather "omniabsent" (p. 132). Swiss humanities are well connected to the dynamics of literary/cultural theory, but without a significant impact 
on domestic intercultural research. Hunkeler deplores what he senses as a retrenchment on mono-lingual and -ethnic alignments in both theory and practice, which prevent Switzerland from becoming a hub of comparatist theory and practice actively mediating between the French, German, and Italian areas. The gap identified by Hunkeler between globalist vistas and domestic practices that seem to be at best "multi-monolingual" (p. 137) might count as a diagnosis for many other European comparatisms.

It is, most certainly, valid for Transylvania, a region that, while being part of contemporary Romania, has an essentially multicultural past, Hungarian, German, Romanian, only accidentally and superficially approached by comparatists. But the Romanian case study, presented by Mihaela Ursa, does not dwell on this incongruity (or tackles it obliquely, by presenting the rare and admirable exception of the post-Hapsburg and multicultural heritage of the neighbouring province of Banat being amply addressed by the project A treia Europă/The Third Europe developed at the Timișoara/Temesvár/ Temeschburg/ University). As the opening essay of the third section, "Proximity and Distance: Comparative Literature and Translation," Ursa's contribution focuses instead on redefining translation as an actual existential condition, in the context of an all-pervasive and "banal" globalization equally experienced by the affluent and the disenfranchised. The essay follows the impact of personally experienced globalization on literature, and especially on literary criticism, which seems compelled to a new, inherently and fully comparative condition. While centering on the Romanian specificities of this transformation (playing on the link between theoretical trends and the fact that Romania has the highest migration recorded in times of peace of the post-WWII era), the essay is also decidedly partial to the model of "world literature" devised by David Damrosch. An option implicitly mitigated in Katre Talviste's view on comparatism and translation theory in Estonia. While highly informative on the institutional and intellectual history of Estonian comparatism, Talviste's essay is centered around one of the most powerful and original contributions of post-Soviet Europe, and of Europe in general, to contemporary comparative theory: Jüri Talvet's vision of the symbiotic nature of culture and literature. This implies an equally existential assumption of translation ("Talvet argues that literary scholarship must never lose touch with the experiential quality of literature" - p. 166) but from a perspective slightly different form the one deployed by Ursa. Talvet's concept of symbiosis expresses a quest for a propitious and wise balance between the model of world literature and comparative literature's praise of diversity and uniqueness. 
DOBRESCU

In her contribution, Aušra Jurgutienè implicitly sets the notion of translation against the entangled histories of Lithuanian comparative literature and of the configuration(s) of Lithuanian identity's historical oscillations between alternative symbioses with the German, Polish, Russian, or "Western" cultures. Jurgutiene insists on the most recent form of symbiosis, also documented in other post-Communist countries, Romania, Estonia, Poland: the profound impact of North American theories whose passionate advocates are émigré scholars reinserted in the national university system.

The fourth and last part of the collection is somewhat miscellaneous (its title itself could hardly be more ecumenical: "Comparative Practices and Perspectives"). The three contributors of which it consists are held together rather by their different takes on the fate of the discipline in their respective countries. Róbert Gáfrik centers his survey of the state of Slovakian comparative literature around the legacy of Dionýz Ďurišin, who not only managed to connect to the international circulation of ideas in spite of the ideological limitations set by the Communist regime, but also made himself noticed through the theory of the interliterary process that he opposed to Étiemblean views still influential at that date (1970s/1980s). Using an approach somewhat reminiscent of the foundational work of Yuri Lotman and his disciples in Tartu, Gáfrik draws a diverse and tensional picture encompassing devoted and diligent continuity (the nine massive volumes on “The Interliterary Process" edited by Pavol Koprda), subtle ironical distancing (as in the quotation of Anton Pokrivčák's opinion that, while fully in line with the dominant Marxist-Leninist ideology of the epoch, the notion of the interliterary process appears as "paradoxically modern" from the perspective of new progressive views on comparatism - p. 200), to a (vague) nostalgia for an epoch of methodological coherence represented by Ďurišin, contrasted to the mixed blessing of contemporary exploded ecclecticism (a view attributed to Dušan Teplan).

If Gáfrik's contribution does not link comparatism in any way to the manner in which Slovaks connect to their former Czech compatriots, the federal past is more present in the Macedonian case. Besides documenting the penetration of the country's literary sciences by most of the contemporary theoretical and methodological trends ("the politics of identity, power, voicelessness, commercialisation, consumerism, etc” - p. 219), Sonja Stojmenska-Elzeser also points to the survival and gradual invigoration of intellectual exchanges between academic communities all over the ex-Yugoslav area, integrated in ever-wider regional projects on cultural and literary Balkanism(s). 
If Gáfrik and Stojmenska-Elzeser take a mainly optimistic stand on the prospects of comparative literature in their countries (the former stressing theoretical effervescence, the later, the contribution of the discipline to a renewed sense of a transnational shared identity), the contribution of the Polish scholar Ewa Łukaszyk strikes a decidedly dramatic and polemical chord. According to her, the roots of comparative literature in Poland extend far back into European cultural and intellectual history. The post-Communist decades occasioned the full contact to and full absorption of all major trends in global humanities (due, among other things, to major scholars returning from their Western exile), and the institutional anchorage of the discipline in the Polish Academe seems profound and stable. But behind these reassuring formal evaluations, Łukaszyk identifies a profoundly disquieting lack of intellectual stamina and vision. This could not be traced back to the country's (in line with the whole region's) "belatedness" with respect to the West, since "an alternative time flow, a distance in relation to our own time, even an anachronism may - as Giorgio Agamben has suggested - turn into a great opportunity of insight and innovation" (p. 234). But this opportunity is wasted "by the intricate ancillary relationship that Polish academics have established with the great centers of scholarship, preventing them from finding space for their own originality while leaving no alternative to the isolationist temptation" (ibid.). I dared reproduce this harsh verdict not only out of respect for Łukaszyk's exigency and frankness, but also because I am confident that many of us, both Western and Eastern Europeans, would (or should) recognize that the same sense of spleen and of intellectual tediousness looms beneath our self-gratulatory academic façades...

To conclude, I would say that this volume offers not only a useful data bank on many historical and institutional aspects of the comparatist communities in the surveyed countries, and a stimulating platform for identifying affinities and boosting future cooperations, but it also opens a new field of research and reflection: the one of comparing comparatisms. Such a meta-disciplinary collective consciousness calls for an intersection of intellectual, political, sociological, cultural perspectives (both diachronic and synchronic) that would fatally exceed the (otherwise perfectly honorable) attempt made in the "Theoretical Introduction" by Frédérique Toudoire-Surlapierre of offering a general rationale for comparative literature. But what already speaks to our comparatist appetites and reflexes is the obvious diversity of motivations behind the manifold intellectual landscape presented in this collection. These motivations stretch from the quest for complex models of cultural identity (confronting both the immense trans-Atlantic Hispanophone area, as well as the Grand Duchy of Luxembourg); to ways of coping with the intricate 
long-term effects of ex-imperial rule (as in the case of Ireland, or Ukraine); to almost hedonistic and erratic "ad hoc constellations mostly dependent on the biographies of the researchers involved" (as diagnosed by Thomas Hunkeler p. 134); to exploring "the nature of the limits and boundaries that have been drawn between different fields of knowledge," and potentially transgressing them - as proposed in the strategic plan for 2015-2020 of The Institute for Comparative Literature Margarida Losa in Porto (quoted p. 44); to managing the irruption of a technological and globalized future in our immediate present, as Mihaela Ursa's hopes for Romanian comparatism go; to Harri Veivo's seminal question: "Would it be exaggerated to say that comparing is surviving?" (p. 91); or to Ewa Łukaszyk call to regaining the dignity of major intellectual undertakings (to boldly go where no one has gone before). Last but not least, to Jüri Talvet's Levinasian creed (vibrantly evoked by Katre Talviste), that, in its very essence, comparative literature is about the face to face encounter of two human beings.

\section{Caius Dobrescu}

caius.dobrescu@gmail.com

Universitatea din București

Facultatea de Litere

Str. Edgar Quinet, 5-7, sector 1, 010017

ROMÂNIA / ROMANIA 